\title{
PERAN SISTEM INFORMASI AKUNTANSI PADA UMKM DI WILAYAH SUMSEL (STUDI KASUS TRAVEL PO BHW)
}

\section{Rika Henda Safitri}

Fakultas Ekonomi, Universitas Sriwijaya

Email: rikahenda@unsri.ac.id dan

\section{Bunga Aulia}

Fakultas Ekonomika dan Bisnis, Universitas Gadjah Mada

Email: bunga.aulia@mail.ugm.ac.id

\section{Riska Tharika}

Fakultas Ekonomika dan Bisnis, Universitas Gadjah Mada

Email: riskatha11997@gmail.com

\begin{abstract}
This paper aims to analyze and improve the profitability of UMKM in the South Sumatra region. This paper takes samples from travel service UMKM in South Sumatra, namely PO Batang Hari Wisata. PO BHW Travel is one of the travel offices in Palembang, South Sumatra. This company has been serving trips with various routes. This research intends to provide a useful information system for businesses like PO BHW Travel.

The type of data used in this study are primary and secondary data. Data collection techniques used in the form of secondary data obtained from trusted journals and articles, as well as from books and other references. Primary data obtained are from the results of field studies through observations about PO $B H W$ Travel. Data obtained from several sources, by conducting interviews with PO BHW Travel owners and direct observation to the business location in the form of ticket sales counters.

It is expected that with the existence of an accounting information system, this travel business can overcome problems in its operations, particularly in terms of recording and providing financial information.
\end{abstract}

Keywords: Sistem Informasi Akuntansi.

\section{LATAR BELAKANG}

Perkembangan teknologi yang pesat memungkinakan para usahawan untuk lebih meningkatkan strategi dalam upaya meningkatkan produktifitas kegiatan usahanya. Di Indonesia, jumlah Usaha Mikro Kecil dan Menengah (UMKM) cukup meningkat terbukti dari data berikut:

\begin{tabular}{ccc}
\hline TAHUN & USAHA MIKRO & USAHA KECIL \\
\hline 2013 & 2.887 .015 & 531.351 \\
2014 & 3.220 .563 & 284.501 \\
2015 & 3.385 .851 & 283.022 \\
\hline
\end{tabular}

Sumber: bps.go.id 
Rika Henda Safitri, Bunga Aulia, Riska Tharika | Peran Sistem Informasi Akuntansi ...

Sistem adalah serangkaian dua atau lebih komponen yang saling terkait dan berinteraksi untuk mencapai tujuan. Sebagian besar sistem terdiri dari sub sistem yang lebih kecil yang mendukung sistem yang lebih besar. Informasi adalah data yang telah dikelola dan diproses untuk memberikan arti dan memperbaiki proses pengambilan keputusan. Proses bisnis adalah serangkai aktivitas dan tugas yang saling terkait, terkoordinasi, dan terstruktur yang dilakukan oleh orang, komputer, atau mesin yang dapat membantu mencapai tujuan tertentu suatu organisasi. Sistem informasi akuntansi adalah proses identifikasi, pengumpulan, dan penyimpanan data serta proses pengembangan, pengukuran, dan komunikasi informasi (Romney, 2016). Kemajuan teknologi komputer dan informasi telah berdampak pada cara pencatatan akuntansi. Sistem Informasi Akuntansi (SIA) yang terkomputerisasi memungkinkan pemakai laporan keuangan dapat melihat laporan keuangan setiap saat dengan lebih cepat dan akurat (Istianingsih \& Wijanto, 2008). Jika Sistem informasi akuntansi merupakan suatu sistem yang terstruktur dalam unit usaha bisnis untuk membantu pelaksanaan kegiatan operasional perusahaan sehari-hari dalam mengatasi permasalahan-permasalahan yang dimulai dari sudut pandang akuntansi yang sesuai dengan kebutuhan perusahaan, membantu manajemen dalam melakukan pengambilan keputusan, dan juga untuk memenuhi pelaksanaan kebijakan pemerintah dalam perusahaan (Darudiato, 2007). Sebuah perusahaan hendaknya mempunyai sistem yang baik agar dapat bertahan dalam persaingan bisnis yang makin hari makin sulit (Utomo, 2012).

Bisnis travel antar jemput dengan berbagai trayek telah membantu masyarakat di Sumatera Selatan khususnya dalam bidang transportasi. Harga terjangkau yang diterapkan, serta banyaknya pilihan trayek ke berbagai daerah di Sumatera Selatan dan sekitarnya, membuat jenis transportasi ini diminati oleh masyarakat. Hal ini dibuktikan dengan menjamurnya bisnis travel antar jemput di berbagai daerah di Sumatera Selatan. Sistem akuntansi pemerintahan di Indonesia mengalami perkembangan dari tahun ke tahun yang diikuti dengan perubahan dasar hukum (Tandaju \& Elim, 2015).Dengan adanya tren usaha ini, muncul berbagai masalah yang dihadapi para pelaku usaha travel, salah satunya adalah ketidakmampuan pelaku usaha untuk menyediakan informasi yang berkaitan dengan kelangsungan usaha tersebut. Untuk mengatasi masalah ini, diperlukan sebuah sistem yang dapat mengolah data menjadi informasi yang berguna bagi bisnis. Perusahaan sebagai pelaku bisnis membutuhkan suatu proses pengolahan transaksi bisnis atau keuangan yang dapat dilakukan dengan proses yang lebih efektif dan efisien yang dapat membantu proses pengolahan data-data keuangan, sehingga munculah konsep sistem informasi akuntansi yang mulai berkembang sebelum abad ke-20 (Tandaju \& Elim, 2015).

Paper ini bertujuan untuk melakukan analisis dan meningkatkan profitabilitas dari UMKM pada wilayah SUMSEL. Paper ini mengambil sample pada UMKM jasa travel di Sumatra Selatan, yaitu PO Batang Hari Wisata. PO BHW Travel merupakan salah satu travel yang memiliki kantor di wilayah Palembang, Sumatera Selatan. Perusahaan ini telah melayani perjalanan dengan berbagai trayek. Penelitian ini bermaksud untuk menyediakan sebuah sistem informasi yang bermanfaat bagi usaha sejenis PO BHW

Jurnal REKSA: Rekayasa Keuangan, Syariah, dan Audit, Vol. 06, No. 02, 2019, pp 123-137| 124 
Rika Henda Safitri, Bunga Aulia, Riska Tharika | Peran Sistem Informasi Akuntansi ...

Travel. Diharapkan dengan adanya sistem informasi akuntansi, usaha travel ini dapat mengatasi masalah-masalah dalam kegiatan operasinya, khususnya dalam hal pencatatan dan penyediaan informasi keuangan.

Dari latar belakang yang telah diuraikan di atas ,maka dapat di rumuskan beberapa masalah untuk menganalisis dan membuat desain sistem informasi akuntansi pada PO BHW Travel sebagai berikut :

1. Bagaimana sistem pencatatatan kegiatan operasional pada PO BHW Travel?

2. Apakah proses pencatatat manual yang digunakan dapat meningkatkan produktivitas usaha tersebut?

3. Bagaimana sistem informasi akuntansi berperan dalam meningkatkan produktivitas usaha tersebut?

Dalam usaha untuk menganalisis dan menerapkan sistem informasi akuntansi berbasis komputer pada UMKM PO BHW. Tujuan dari tulisan ini untuk mencari jawaban atas rumusan masalah sebagai berikut:

1. Untuk menganalisis bagaimana pencatatan kegiatan operasional pada PO BHW Travel.

2. Untuk menganalisis apakah proses pencatatat secara manual dapat meningkatkan produktivitas usaha tersebut.

3. Untuk menganalisis dan merancang sistem informasi akuntansi dalam upaya meningkatkan produktivitas usaha tersebut.

\section{KAJIAN LITERATUR}

\section{Sistem Informasi Akuntansi}

Ada tiga konsep yang mempengaruhi Sistem Informasi Akuntasi, yaitu: 1) Konsep sistem; 2) Konsep informasi; dan 3) Konsep akuntansi. Sistem adalah rangkaian dari dua atau lebih komponen-komponen yang saling berhubungan, yang berinteraksi untuk mencapai suatu tujuan. Sistem hampir selalu terdiri dari beberapa subsistem kecil, yang masing-masing melakukan fungsi khusus yang penting untuk dan mendukung bagi sistem yang lebih besar, tempat mereka berada. Sedangkan informasi adalah data yang telah diatur dan diproses untuk memberikan arti dan memperbaiki proses pengambilan keputusan. Jadi, sistem informasi akuntansi adalah proses identifikasi, pengumpulan, dan penyimpanan data serta proses pengembangan, pengukuran, dan komunikasi informasi. (Romney \& Steinbart, 2006).

Sistem Informasi Akuntansi juga dapat diartikan sebagai sistem berbasis komputer yang memiliki kelebihan yaitu mempermudah perusahaan dalam menghasilkan informasi yang efektif dan efisien serta membantu perusahaan dalam mengambil keputusan dan mempermudah melakukan kontrol secara tepat terhadap aset organisasi.

Adapun Wilkinson et al. (2000, p8) mengatakan seperti yang dikutip oleh (Darudiato, 2007) bahwa Sistem Informasi Akuntansi mempunyai tujuan sebagai berikut: 
Rika Henda Safitri, Bunga Aulia, Riska Tharika | Peran Sistem Informasi Akuntansi ...

a. Untuk mendukung operasi sehari-hari. Transaksi dalam perusahaan merupakan operasi sehari-hari yang dilakukan secara rutin. Adapun transaksi terdiri dari:

1) Transaksi akuntansi seperti penjualan biasanya menggunakan Sistem Informasi Akuntansi untuk pemrosesan.

2) Transaksi non-akuntansi seperti melakukan pemesanan, pada akhirnya akan mengarah kepada transaksi akuntansi. Misalnya jika suatu pesanan telah terpenuhi, dan pengiriman pesanan telah diterima, maka akan dicatat sebagai transaksi akuntansi.

b. Untuk menunjang pengambilan keputusan oleh pembuat keputusan internal.

c. Untuk memenuhi kewajiban seperti pelaporan finansial kepada para stockholder.

Sistem informasi meliputi berbagai macam aktivitas yang berkaitan dengan siklus pemrosesan akuntansi perusahaan. Transaksi-transaksi yang terjadi di perusahaan dapat dikelompokkan menjadi empat siklus aktivitas bisnis (siklus operasional) yang sifatnya umum yaitu:

1. Siklus pendapatan (revenue cycle), terdiri dari transaksi yang berkaitan dengan penjualan barang atau jasa yang merupakan output atau produk perusahaan.

2. Siklus pengeluaran (expenditure cycle), terdiri dari transaksi pengadaan bahan baku, barang dagangan, bahan pembantu, berikut biaya faktor input lainnya.

3. Siklus produksi (production cycle), terdiri dari transaksi yang berkaitan dengan kegiatan manufaktur yang mengubah bahan baku menjadi produk.

4. Siklus keuangan (finance cycle), terdiri dari transaksi yang berkaitan dengan kegiatan penerimaan dan pengeluaran kas sebagai akibat dari siklus pendapatan, pengeluaran dan produksi.

Keempat siklus aktivitas bisnis tersebut didukung oleh siklus kelima yaitu siklus pelaporan keuangan, yang memproses data akuntansi dari keempat siklus operasi di atas untuk menghasilkan laporan keuangan yang sesuai dengan standar akuntansi keuangan (SAK), untuk pihak eksternal dan laporan manajemen untuk pihak internal perusahaan (Musmini, 2013).

\section{Sistem Informasi Akuntansi bagi Organisasi}

Proses bisnis dalam (Romney \& Steinbart, 2012) adalah serangkaian aktivitas dan tugas yang saling terkait, terkoordinasi, dan terstruktur yang dilakukan oleh orang, komputer, atau mesin yang dapat membantu mencapai tujuan tertentu suatu organisasi.

Bisnis pada umumnya bertujuan menyediakan nilai untuk pelanggan mereka. Sistem Informasi Akuntansi (SIA) diyakini dapat menambah nilai bagi suatu bisnis dengan cara memberikan informasi yang akurat dan tepat waktu. SIA yang dirancang dengan baik dapat mencapai hal tersebut dengan cara: 1) Memperbaiki kualitas dan mengurangi biaya untuk menghasilkan produk atau jasa; 2) Memperbaiki efisiensi jalannya suatu proses; 3) Memperbaiki pengambilan keputusan; 4) Berbagi pengetahuan dan keahlian yang selanjutnya dapat memperbaiki proses operasi perusahaan, dan bahkan memberikan 
Rika Henda Safitri, Bunga Aulia, Riska Tharika | Peran Sistem Informasi Akuntansi ...

keunggulan kompetitif. Sistem Informasi yang dirancang dengan baik juga dapat membantu meningkatkan laba perusahaan dengan memperbaiki efisiensi dan efektivitas rantai persediannya. (Romney \& Steinbart, 2012)

Dalam penelitian (Awosejo, O.J, Kekwaletswe, R, M, Pretorius, P and Zuva, 2013) sebelumnya, menunjukkan bahwa keberhasilan penerapan sistem informasi akuntansi memiliki banyak manfaat seperti; peningkatan kualitas kerja, peningkatan arus produk, peningkatan fleksibilitas, peningkatan kemampuan multifungsi, peningkatan motivasi dalam menggunakan aplikasi perangkat lunak, peningkatan kemampuan karyawan dalam memecahkan masalah, meningkatkan produktivitas dan kinerja dalam hal biaya produksi, dan akhirnya meningkatkan penekanan pada integrasi pemasok.

\section{METODA PENELITIAN}

Jenis data yang digunakan dalam penelitian ini adalah data primer dan sekunder. Dalam penelitian ini menggunakan pendekatan observasi dan wawancara dengan owner PO BHW Travel. Penelitian yang dilakukan adalah penelitian deskriptif. Penelitian yang dilakukan menjelaskan aspek-aspek yang relevan dengan penelitian yaitu untuk mengetahui bagaimana peran sistem informasi akuntansi berbasis komputer untuk meningkatkan efektifitas dan efisiensi pada umkm di wilayah sumsel.

Penelitian ini dilakukan pada PO BHW Travel yang berlokasi di Jalan TP. Rustam Effendi No.35, Palembang. Penelitian dilaksanakan pada bulan Maret - April 2019. Teknik pengumpulan data yang digunakan yakni berupa data sekunder yang didapat dari jurnal maupun artikel terpercaya, serta dari buku dan referensi lainnya. Data primer yang didapat yakni dari hasil studi lapangan melalui observasi mengenai PO BHW Travel. Data diperoleh dari beberapa sumber, dengan melakukan wawancara terhadap owner PO BHW Travel dan observasi langsung ke lokasi usaha berupa loket penjualan tiket.

Tahap - tahap dalam penelitian:

1) Tahap peninjauan pustaka, pada tahap ini akan dikumpulkan data dari sumber kajian pustaka untuk ditarik berbagai hipotesis.

2) Tahap persiapan, pada tahapan ini diadakan listing dari daerah yang akan diteliti.

3) Pengumpulan data, pada tahapan ini untuk memperoleh data dan berbagai informasi yang diperlukan, akan dilakukan studi lapangan untuk mengunjungi tempat usaha PO BHW Travel.

4) Analisa, pada tahapan ini data diolah dengan cara menganalisa data mentah.

5) Penarikan kesimpulan, pada tahap ini kesimpulan disempurnakan dari data yang telah disimpulkan sebelumnya, dengan mencari setiap makna dari verifikasi data.

\section{HASIL DAN PEMBAHASAN}

\section{Pemesanan Tiket}

Pada prosedur ini, mula-mula calon penumpang mengajukan permintaan mengenai jadwal keberangkatan yang ada baik dengan datang langsung ke loket dan memesan tiket secara lisan maupun dengan tidak datang langsung ke loket /via telepon ke bagian

Jurnal REKSA: Rekayasa Keuangan, Syariah, dan Audit, Vol. 06, No. 02, 2019, pp 123-137| 127 
Rika Henda Safitri, Bunga Aulia, Riska Tharika | Peran Sistem Informasi Akuntansi ...

operasional atau bagian keuangan loket. Bagian operasional atau bagian keuangan mengecek jadwal keberangkatan dan ketersediaan bangku sesuai permintaan calon penumpang. Setelah itu bagian operasional atau bagian keuangan memberikan informasi tentang ketersediaan bangku yang ada pada calon penumpang. Calon penumpang mengkonfirmasi jadwal keberangkatan dan posisi bangku yang ada. Setelah calon penumpang melakukan pemesanan, bagian operasional atau bagian keuangan akan menerima pemesanan tiket dan mencatat konfirmasi pemesanan tersebut secara manual di buku pemesanan. Bagian operasional atau keuangan akan menerima konfirmasi kembali mengenai pembatan tiket atau penggantian jadwal. Jika terjadi pembatalan tiket, maka bagian terkait akan menghapus data/ melakukan pencoretan di buku pemesanan. Apabila terjadi penggantian jadwal maka bagian terkait akan meninjau kembali data pemesanan.

\section{Penerimaan Kas}

Penerimaan kas diperoleh dari penjualan tiket perjalanan kepada penumpang. Biasanya bagian operasional atau bagian keuangan menerima pembayaran lunas calon penumpang sesuai buku pemesanan. Setelah menerima pembayaran, bagian operasional atau bagian keuangan akan men-ceklist nama penumpang yang membayar pada buku pemesanan dan membuat kwitansi atas transaksi penjualan tiket tersebut. Bagian operasional atau bagian keuangan akan memberikan kwitansi tersebut sebagai tiket perjalanan kepada penumpang. Untuk calon penumpang yang belum melakukan pembayaran di loket, bagian operasional atau bagian keuangan memberikan tiket dan otorisasi kepada sopir untuk menerima pembayaran tiket di alamat jemput.

\section{Pra-Keberangkatan Penumpang}

Pada prosedur ini, bagian operasional atau bagian keuangan melakukan konfirmasi kepada calon penumpang apakah masih akan melakukan perjalanan atau tidak, jika calon penumpang menyetujui untuk tetap melakukan perjalanan maka fungsi yang bertanggung jawab menindaklanjuti proses selanjutnya, jika calon penumpang tidak menyetujui untuk tetap melakukan perjalanan maka dianggap sebagai pembatalan pembelian tiket oleh calon penumpang tersebut dan bagian yang bertanggung jawab akan mencoret data penumpang tersebut di buku pemesanan. Bagian operasional atau bagian keuangan akan melihat dan mengecek daftar nama penumpang yang sudah di-ceklist sesuai tanggal dan jam keberangkatan. Lalu, Bagian operasional atau bagian keuangan juga membuat dan mengisi surat jalan ( hari/tanggal, jam, no plat mobil, nama sopir dan list nama, alamat jemput, alamat antar) berdasarkan data nama penumpang yang sudah di-ceklist sesuai jadwal keberangkatan. Bagian keuangan akan mengkonfirmasi kembali mengenai keberangkatan penumpang dari alamat jemput. Selanjutnya bagian operasional atau bagian keuangan menyerahkan surat jalan tersebut kepada sopir. Sopir mengabsen penumpang yang telah ada dan berangkat dari lokasi loket. Untuk penumpang yang tidak berangkat dari lokasi loket, sopir akan menjemput penumpang tersebut sesuai alamat jemput yang ada dan tertera di surat jalan atau yang sudah diinformasikan bagian operasional atau bagian keuangan, baik penumpang yang sudah maupun belum

Jurnal REKSA: Rekayasa Keuangan, Syariah, dan Audit, Vol. 06, No. 02, 2019, pp 123-137| 128 
Rika Henda Safitri, Bunga Aulia, Riska Tharika | Peran Sistem Informasi Akuntansi ...

melakukan pembayaran. Untuk penumpang yang belum melakukan pembayaran di loket, sopir akan menagih pembayaran tiketnya di alamat jemput penumpang dan memberikan kwitansi pembayaran sebagai tiket kepada penumpang

\section{Penyetoran Dan Pelaporan}

Setelah melakukan perjalanan Palembang-Baturaja dan Baturaja-Palembang, sopir melapor dan menyetor sisa kwitansi serta surat jalan PLG-ME dan ME-PLG ke bagian keuangan. Bagian keuangan menverifikasi surat jalan dan meng-update buku pemesanan atas penerimaan komisi tersebut. Verifikasi surat jalan PLG-ME dilakukan untuk pengecekan kebenaran jumlah terakhir penumpang di meeting point berdasarkan bukti kwitansi yang sudah diserahkan ke sopir untuk menghitung update total penjualan tiket dan tambahan komisi. Sedangkan surat jalan ME-PLG digunakan untuk melihat total penjualan tiket setelah dikurangi komisi loket Baturaja untuk perhitungan upah sopir.

Keuangan akan menghitung secara manual total penjualan tiket bersih untuk diserahkan ke pemilik. Penjualan tiket bersih diperoleh dari total penjualan tiket pp (pulang pergi) dikurangi biaya bbm dan sopir (sebesar 15\% dari penjualan tiket setelah komisi dan pengurangan bbm). Bagian keuangan akan memberikan upah sopir beserta penjualan bersih ke sopir. Uang penjualan bersih akan disetorkan sopir ke owner. Setelah itu, bagian keuangan bertugas untuk merekap seluruh komisi loket setiap hari untuk pembuatan laporan akhir bulan rekapitulasi komisi loket. Bagian keuangan menyetor total komisi loket dan melaporkan rekapitulasi komisi loket setiap akhir bulan.

Untuk lebih jelas, hasil observasi sistem informasi penjualan yang sedang berjalan pada PO.BHW Travel dapat dilihat pada bagan berikut:

SKEMA SISTEM

\begin{tabular}{|c|c|c|c|c|}
\hline Komponen & $\begin{array}{c}\text { Pemesanan \& Penerimaan } \\
\text { Kas }\end{array}$ & Pra-keberangkatan & & $\begin{array}{l}\text { Penyetoran dan } \\
\text { pelaporan }\end{array}$ \\
\hline INPUT & $\begin{array}{l}\text { Informasi pemesanan } \\
\text { secara lisan (Nama, } \\
\text { tanggal keberangkatan, } \\
\text { tujuan, jam } \\
\text { keberangkatan, urutan } \\
\text { bangku). Lalu dicatat di } \\
\text { Buku pemesanan tiket. }\end{array}$ & $\begin{array}{l}\text { Buku pemesanan } \\
\text { tiket (ticket } \\
\text { booking) yang } \\
\text { sudah di ceklist. }\end{array}$ & 2. & $\begin{array}{l}\text { Surat Jalan dari } \\
\text { Palembang dan } \\
\text { Muaraenim, } \\
\text { Surat jalan } \\
\text { Muaraenim - } \\
\text { Palembang, } \\
\text { Klarifikasi sopir } \\
\text { secara lisan atas } \\
\text { penjemputan calon } \\
\text { penumpang di } \\
\text { buktikan dengan } \\
\text { tiket yang tersisa } \\
\text { yang sebelumnya } \\
\text { diberi-kan bagian } \\
\text { keuangan /bagian } \\
\text { operasional saat } \\
\text { pra-keberangkatan. }\end{array}$ \\
\hline
\end{tabular}

Jurnal REKSA: Rekayasa Keuangan, Syariah, dan Audit, Vol. 06, No. 02, 2019, pp 123-137| 129 
Rika Henda Safitri, Bunga Aulia, Riska Tharika | Peran Sistem Informasi Akuntansi ...

PROSES

OUTPUT

FUNGSI YANG TERKAIT

\section{Permintaan jadwal keberangkatan secara lisan atau via telepon/ hp dan Pembayaran tiket lunas.}

2.Pengecekan jadwal keberangkatan dan ketersediaan bangku sesuai permintaan lalu pihak travel melakukan Pen-ceklis- an nama penumpang pada buku pemesanan dan pembuatan kwitansi.

3.Pemberian informasi tentang ketersediaan bangku serta jadwal keberangkatan yang tersedia dari pihak travel dan pihak travel memberi kwitansi sebagai tiket penumpang.

4.Konfirmasi ulang jadwal keberangkatan dan posisi bangku

5.Penerimaan pemesanan dan pencatatan di buku pemesanan.

6.Peninjauan kembali pemesan dan pembayaran tiket dapat dilakukan langsung dari pemesan ke loket, tetapi pihak travel memberikan otorisasi kepada supir untuk bisa menerima pembayaran tiket dan memberikan tiket di alamat jemput.

1.Buku pemesanan tiket (ticket booking).

2.Tiket sebagai kwitansi bukti transaksi untuk penumpang.

Calon penumpang, bagian operasional ,bagian keuangan, sopir

$\begin{array}{lc}\text { 1.Mengkonfirmasi } & \text { 1.Pelaporan dan } \\ \text { ulang } & \text { penyetoran uang } \\ \text { penumpang. } & \text { komisi atas } \\ \text { 2.Check } & \text { penerimaan kas di } \\ \text { daftar nama } & \text { meeting point oleh } \\ \text { penumpang yang } & \text { sopir. } \\ \text { sudah di-ceklis. } & \text { 2.Verifikasi surat jalan } \\ \text { 3.Pengisian surat } & \text { dan meng-update } \\ \text { jalan ( hari/ } & \text { buku pemesanan. } \\ \text { tanggal, jam, no } & \text { 3.Penjualan besih } \\ \text { plat mobil, nama } & \text { serta upah sopir pp } \\ \text { sopir dan list } & \text { (pulang pergi). } \\ \text { nama, alamat } & \text { 4.Penyetoran penjualan } \\ \text { jemput, alamat } & \text { bersih dan surat } \\ \text { antar. } & \text { jalan oleh sopir ke } \\ \text { 4.Menyerahkan } & \text { owner } \\ \text { surat jalan } & \text { 5.Perekapan total } \\ \text { kepada sopir } & \text { komisi loket harian. } \\ \text { 5.Konfirmasi } & \text { 6.Penyetoran uang dan } \\ \text { kembali } & \text { laporan rekapitulasi } \\ \text { penumpang yang } & \text { komisi loket kepada } \\ \text { dijemput. } & \text { owner diakhir bulan. }\end{array}$

6.Absensi penumpang

7.Penjemputan dan penagihan oleh sopir.

Surat Jalan (satu rangkap) untuk sopir

Tidak ada Laporan Penjualan Tiket, hanya laporan komisi loket

Penumpang, bagian operasional, bagian keuangan, sopir
Bagian Keuangan , dirut, sopir 
Rika Henda Safitri, Bunga Aulia, Riska Tharika | Peran Sistem Informasi Akuntansi ...

\begin{tabular}{|c|c|c|c|}
\hline MEDIA & $\begin{array}{l}\text { Buku, ATK, telepon/hp, } \\
\text { kertas, kalkulator }\end{array}$ & $\begin{array}{l}\text { Kertas , ATK, } \\
\text { telepon }\end{array}$ & $\begin{array}{l}\text { - Kertas, ATK, } \\
\text { kalkulator }\end{array}$ \\
\hline PENGENDALIAN & $\begin{array}{l}\text { 1.Pencatatan data } \\
\text { pemesanan sesuai } \\
\text { konfirmasi yang } \\
\text { diberikan oleh calon } \\
\text { penumpang. } \\
\text { 2.Pemilik stand by di loket } \\
\text { sampai jam } 08.00 \mathrm{WIB} \text {. }\end{array}$ & $\begin{array}{l}\text { 1.Pengecekan } \\
\text { penumpang/ } \\
\text { absen } \\
\text { penumpang } \\
\text { sesuai surat } \\
\text { jalan. } \\
\text { 2.Peng-update } \\
\text { secara manual } \\
\text { data penumpang } \\
\text { yang melakukan } \\
\text { pembayaran di } \\
\text { alamat jemput } \\
\text { pada surat jalan. }\end{array}$ & $\begin{array}{l}\text { Penyetoran: } \\
\text { - Penghitungan } \\
\text { penjualan tiket setiap } \\
\text { hari } \\
\text { - penghitungan dan } \\
\text { rekap komisi loket } \\
\text { sesuai surat jalan } \\
\text { yang dibuat . } \\
\text { Pelaporan: } \\
\text { Tidak ada }\end{array}$ \\
\hline
\end{tabular}

\section{ANALISIS KENDALA DAN PERMASALAHAN}

Berdasarkan hasil observasi tersebut, ada beberapa kendala dan permasalahan yang akan digambarkan dalam bagan skema berikut:

\begin{tabular}{|c|c|c|c|}
\hline Komponen & $\begin{array}{l}\text { Pemesanan dan } \\
\text { Penerimaan Kas }\end{array}$ & Pra - Keberangkatan & $\begin{array}{l}\text { Penyetoran dan } \\
\text { Pelaporan }\end{array}$ \\
\hline INPUT & $\begin{array}{l}\text { Elemen informasi } \\
\text { tidak lengkap dan } \\
\text { merata } \\
\text { Buku pemesanan } \\
\text { tiket belum } \\
\text { komputerisasi }\end{array}$ & $\begin{array}{l}\text { Buku pemesanan } \\
\text { manual dan hanya } \\
\text { berupa ceklist nama }\end{array}$ & Tidak ada \\
\hline PROSES & $\begin{array}{l}\text { Kurang efisiensi } \\
\text { waktu (manual) } \\
\text { Proses belum secara } \\
\text { komputerisasi }\end{array}$ & $\begin{array}{l}\text { Proses belum secara } \\
\text { komputerisasi }\end{array}$ & $\begin{array}{l}\text { Penyetoran uang oleh } \\
\text { sopir }\end{array}$ \\
\hline OUTPUT & $\begin{array}{l}\text { Buku pemesanan } \\
\text { belum } \\
\text { terkomputerisasi } \\
\text { Kwitansi masih } \\
\text { manual }\end{array}$ & Surat jalan manual & $\begin{array}{l}\text { Hanya laporan komisi } \\
\text { loket per bulan }\end{array}$ \\
\hline $\begin{array}{l}\text { FUNGSI YANG } \\
\text { TERKAIT }\end{array}$ & $\begin{array}{l}\text { Belum ada } \\
\text { pemisahan tugas }\end{array}$ & $\begin{array}{l}\text { Belum ada pemisahan } \\
\text { tugas }\end{array}$ & $\begin{array}{l}\text { Belum ada pemisahan } \\
\text { tugas }\end{array}$ \\
\hline MEDIA & $\begin{array}{l}\text { Boros dalam } \\
\text { pemakaian buku }\end{array}$ & Tidak ada & Tidak ada \\
\hline PENGENDALIAN & $\begin{array}{l}\text { Output mudah } \\
\text { rusak, hilang dan } \\
\text { manipulasi }\end{array}$ & $\begin{array}{l}\text { Output mudah rusak, } \\
\text { hilang dan manipulasi }\end{array}$ & $\begin{array}{l}\text { Output mudah rusak, } \\
\text { hilang dan manipulasi }\end{array}$ \\
\hline
\end{tabular}


Rika Henda Safitri, Bunga Aulia, Riska Tharika | Peran Sistem Informasi Akuntansi ...

\section{SOLUSI YANG DITAWARKAN}

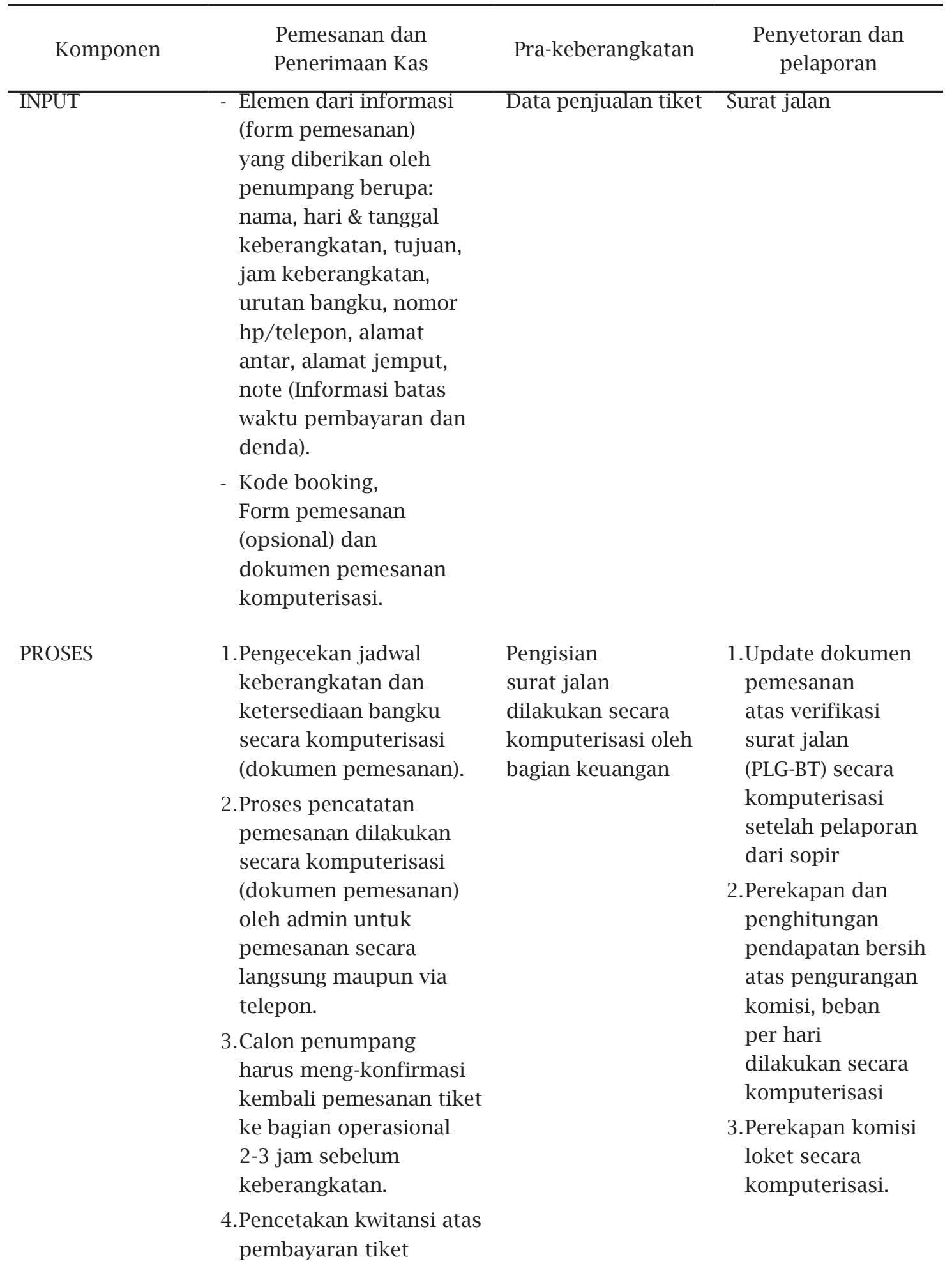


Rika Henda Safitri, Bunga Aulia, Riska Tharika | Peran Sistem Informasi Akuntansi ...

\begin{tabular}{|c|c|c|c|}
\hline OUTPUT & $\begin{array}{l}\text { - Kode booking } \\
\text { - Print-out kwitansi } \\
\text { - Dokumen penerimaan kas }\end{array}$ & $\begin{array}{l}\text { Print-out surat jalan } \\
2 \text { rangkap. }\end{array}$ & $\begin{array}{l}\text { Print-out Laporan } \\
\text { penjualan tiket. }\end{array}$ \\
\hline $\begin{array}{l}\text { FUNGSI YANG } \\
\text { TERKAIT }\end{array}$ & Penumpang, admin & Penumpang, admin & $\begin{array}{l}\text { Loket Baturaja, } \\
\text { Admin, Direktur } \\
\text { Utama, Sopir }\end{array}$ \\
\hline MEDIA & Komputer, Printer, Kertas & $\begin{array}{l}\text { Komputer, kertas, } \\
\text { printer }\end{array}$ & $\begin{array}{l}\text { Komputer, kertas, } \\
\text { printer }\end{array}$ \\
\hline PENGENDALIAN & $\begin{array}{l}\text { - Proses pemanggilan } \\
\text { data yang cenderung } \\
\text { lebih efektif dan efisien } \\
\text { karena pencatatan data } \\
\text { penumpang dilakukan } \\
\text { secara komputerisasi. } \\
\text { - Adanya pemisahan } \\
\text { bagian, yang mana } \\
\text { tanggung jawab untuk } \\
\text { pemesanan tiket oleh } \\
\text { bagian operasional. } \\
\text { - Lebih terjaminnya } \\
\text { keamanan data dari } \\
\text { manipulasi, pembatalan } \\
\text { pemesanan atau } \\
\text { kehilangan karena } \\
\text { diproses secara } \\
\text { komputerisasi. } \\
\text { - Adanya pemisahan } \\
\text { bagian, yang mana } \\
\text { tanggung jawab untuk } \\
\text { penerimaan kas oleh } \\
\text { bagian keuangan. } \\
\text { - Tidak ada manipulasi } \\
\text { data pemesanan dan } \\
\text { data penerimaan kas } \\
\text { karena dokumen } \\
\text { pemesanan dan bukti } \\
\text { transaksi diproses } \\
\text { secara komputerisasi. }\end{array}$ & $\begin{array}{l}\text { - } \text { Adanya arsip } \\
\text { surat jalan } \\
\text { untuk bagian } \\
\text { keuangan. } \\
\text { - } \quad \text { Adanya } \\
\text { pemisahan } \\
\text { bagian, yang } \\
\text { mana tanggung } \\
\text { jawab untuk pra } \\
\text { - keberangkatan } \\
\text { oleh bagian } \\
\text { keuangan. }\end{array}$ & $\begin{array}{l}\text { - Penghitungan } \\
\text { jumlah pendapatan } \\
\text { bersih per hari } \\
\text { setiap unit mobil } \\
\text { lebih terkendali / } \\
\text { terkontrol. } \\
\text { - Adanya arsip surat } \\
\text { jalan untuk bagian } \\
\text { keuangan. }\end{array}$ \\
\hline
\end{tabular}


Rika Henda Safitri, Bunga Aulia, Riska Tharika | Peran Sistem Informasi Akuntansi ...

\section{FLOWCHART}

\begin{tabular}{|c|c|c|}
\hline $\begin{array}{c}\text { PEMESANAN TIKET } \\
\text { DAN PENERIMAAN KAS }\end{array}$ & PRA KEBERANGKATAN & $\begin{array}{c}\text { PENYETORAN } \\
\text { DAN PELAPORAN }\end{array}$ \\
\hline
\end{tabular}

KET :
A : Pelanggan
B : Kasir
C : Manager
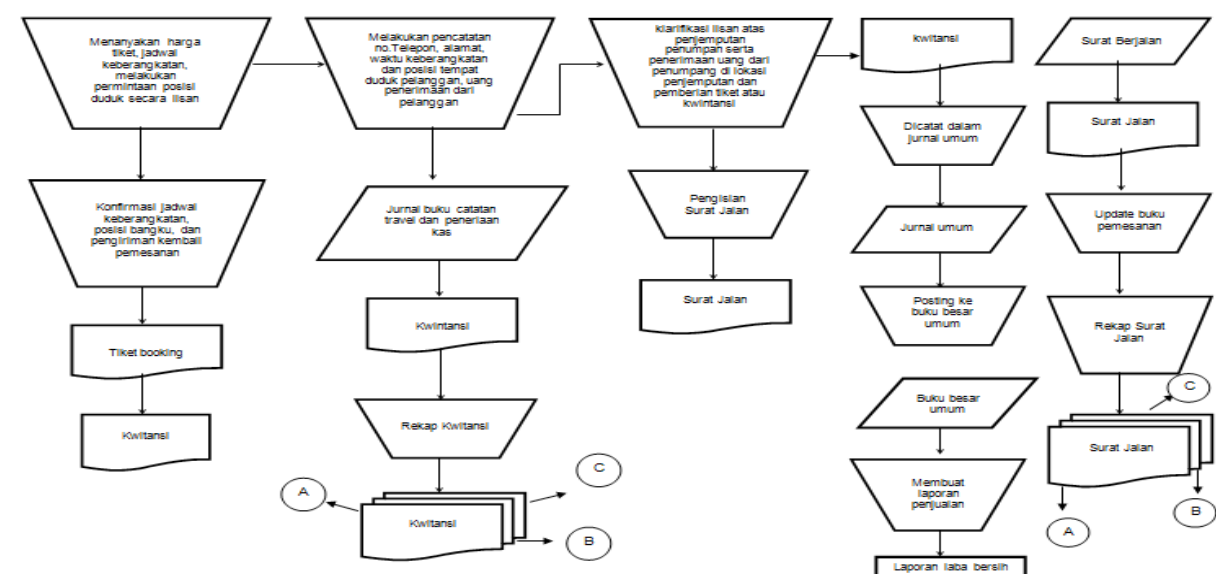

FLOWCHART

PEMESANAN TIKET DAN PENERIMAN KAS

KET :
A : Pelanggan
B : Kasir
C : Manager

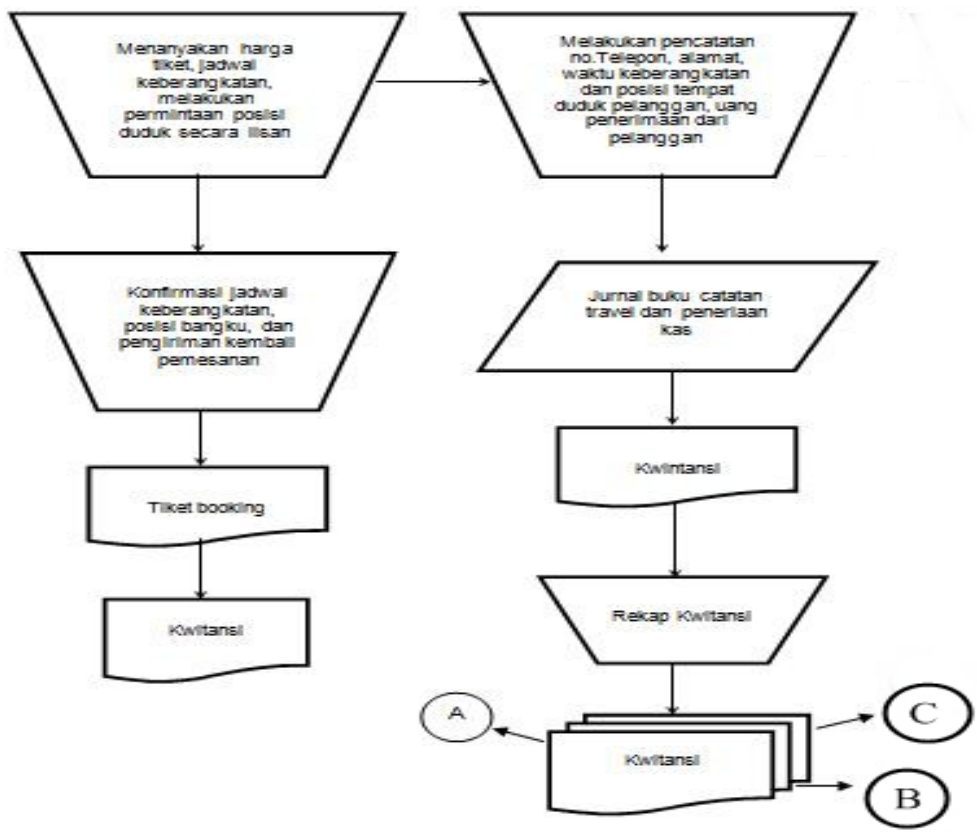


Rika Henda Safitri, Bunga Aulia, Riska Tharika | Peran Sistem Informasi Akuntansi ...

\section{FLOWCHART}

PRA KEBERANGKATAN

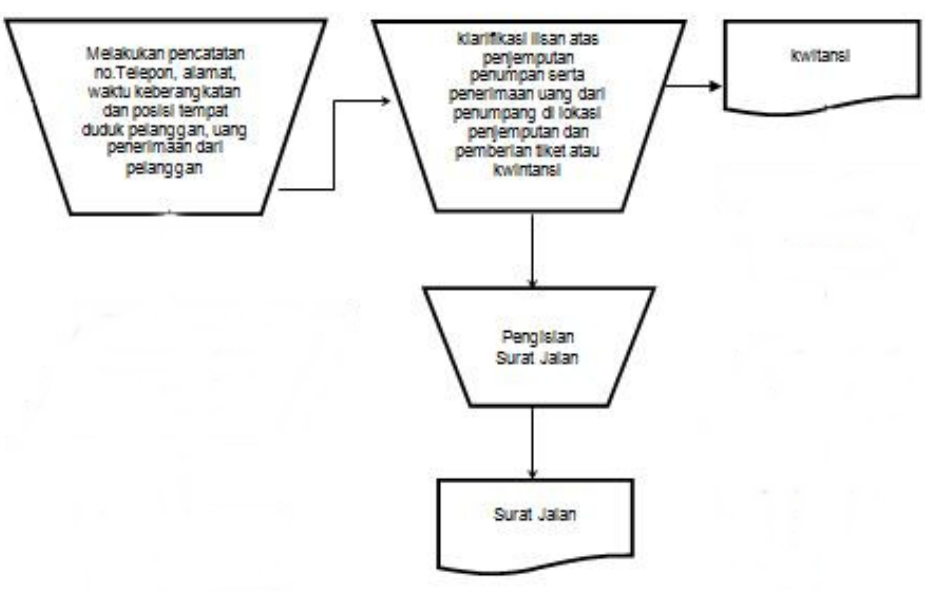

FLOWCHART

PENYETORAN DAN PELAPORAN KAS

KET :

A : Pelanggan

B : Kasir

$\mathrm{C}:$ Manager

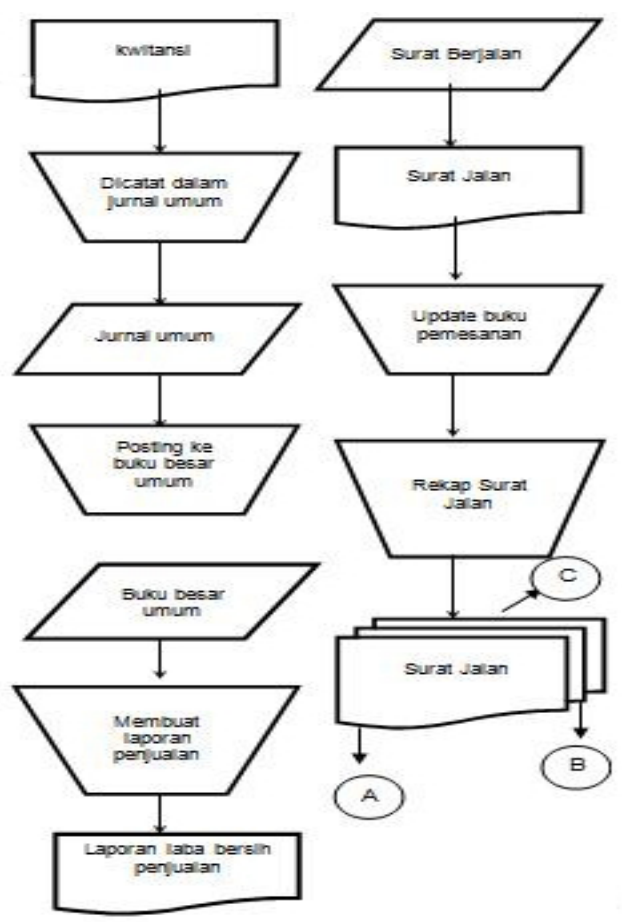

\section{SIMPULAN DAN SARAN}

Berdasarkan peninjauan hasil observasi yang telah dilakukan, pengembangan sistem yang baru akan menghasilkan kinerja yang lebih efektif dan efisien. Pengembangan sistem penjualan tiket yang baru akan mempermudah perusahaan untuk mengakses data secara mudah serta hemat waktu. Pengembangan sistem yang kami tawarkan akan 
Rika Henda Safitri, Bunga Aulia, Riska Tharika | Peran Sistem Informasi Akuntansi ...

membantu PO. BHW Travel untuk meningkatkan kualitas pelayanan kepada pelanggan tanpa menghabiskan biaya besar.

Sistem baru yang kami tawarkan adalah pemrosesan sistem penjualan berbasis komputer, dalam menjalankan sistem ini diperlukan satu unit komputer yang sudah terpasang program yang kami usulkan. Adapun program yang kami usulkan menggunakan Micosoft Office yang kami sesuaikan dengan kebutuhan customer. Dengan sistem yang kami usulkan, tidak ada lagi bagian operasional dan bagian keuangan pada fungsi terkait, yang ada hanya admin yang akan secara langsung terkait pada sistem ini. Proses-proses yang awalnya dilakukan secara manual, dengan sistem yang kami usulkan cukup meng-input data secara komputerisasi seperti peng-inputan data pemesanan, pembuatan kode booking, pencatatan dan update database, pembuatan kwitansi, surat jalan dan laporan komisi, sehingga lebih efektif dan efisien dalam kinerjanya dan dapat meminimalisir terjadinya kesalahan pencatatan, penjumlahan dan kesalahan-kesalahan lain yang disebabkan oleh kelalaian manusia (human error).

Pembuatan laporan penjualan tiket sacara komputerisasi merupakan salah satu poin penting dalam sistem yang kami usulkan, yang pada sistem lama tidak adanya laporan penjualan tiket, pada sistem ini input penjualan akan langsung diproses oleh komputer dan menghasilkan output berupa laporan komisi loket dan laporan penjualan tiket pada periode tertentu dengan cepat dan akurat. Laporan penjualan ini menjadi informasi yang sangat berguna bagi manajemen/ pemilik PO BHW Travel guna pengambilan keputusan.

\section{DAFTAR PUSTAKA}

Awosejo, O.J, Kekwaletswe, R, M, Pretorius, P And Zuva, T. (2013). The Effect Of Accounting Information Systems In Accounting. International Journal Of Advanced Computer Research, 1(2), 21-31.

Darudiato, S. (2007). Analisis Dan Perancangan Sistem Informasi Akuntansi Pt. Maju Bersama (Studi Kasus: Penjualan Dan Piutang Usaha). Seminar Nasional Aplikasi Teknologi Informasi, 2007(Snati), 1907-5022.

Djakman, C. D. (2016). Pengantar Akuntansi - Adaptasi Indonesia Edisi 25. Jakarta: Salemba Empat.

Istianingsih, \& Wijanto, S. H. (2008). Analisis Keberhasilan Penggunaan Perangkat Lunak Akuntansi Ditinjau Dari Persepsi Pemakai (Studi Implementasi Model Keberhasilan Sistem Informasi). Jurnal Akuntansi Dan Keuangan Indonesia, 5(1), 50-76.

Kurniawati, E. P., Nugroho, P. I., \& Arifin, C. (2012). Penerapan Akuntansi Pada Usaha Mikro Kecil Dan Menengah (UMKM). Informatics And Business Institute Darmajaya, 10(2).

Musmini, L. S. (2013). Sistem Informasi Akuntansi Untuk Menunjang Pemberdayaan Pengelolaan Usaha Kecil. Vokasi Jurnal Riset Akuntansi, 2(1), 62-81.

S. Papalangi, \& Riska. (2013). Penerapan Spi Dalam Menunjang Efektivitas Pemberian Kredit Ukm Pada Pt. Bri (Persero) Tbk Manado. Jurnal Emba, 1(3), 1212-1220. 
Rika Henda Safitri, Bunga Aulia, Riska Tharika | Peran Sistem Informasi Akuntansi ...

Tandaju, I. ., \& Elim, I. (2015). Evaluasi Penerapan Pengendalian Intern Siklus Penerimaan Kas Pada Dinas Pendapatan, Pengelolaan Keuangan Dan Aset Daerah Kabupaten Kepulauan Sangihe. Riset Ekonomi, Manajemen, Bisnis Dan Akuntansi, 3(1), 912-922. Https://Doi.Org/ISSN 2303-1174

Utomo, S. L. (2012). Perancangan Sistem Penjualan Dalam Rangka Meningkatkan. Jurnal Ilmiah Mahasiswa Akuntansi, 1(1), 79-85.

Romney, M. B., \& Steinbart, P. J. (2012). Sistem Informasi Akuntansi. Jakarta: Salemba Empat.

Warren, C. S., Reeve, J. M., Duchac, J., Suhardianto, N., Kalanjati, D. S., Jusuf, A. A., \& 